\title{
Human enhancement, biocyborg and self-experimentation: biopower in the age of synthetic biology and gene editing
}

\author{
Léo Pio-Lopez
}

2020

\begin{abstract}
Synthetic biology and gene editing open new possibilities for human enhancement requiring ethical, societal and biopolitical considerations to evaluate its implications on the biopower and the human species. In this article, from a critical and exploratory analysis, we advocate that recent biotechnological developments allowed by synthetic biology (including gene editing) are transforming the line of forces of biopower and biopolitics. After having described the paradigm of life as an engineering discipline conveyed by synthetic biology, we first analyse using the concept of somatechnology how this technoscience is transforming the figure of the cyborg towards the biocyborg, blurring the distinctions natural/artificial and man/machine. In second, we investigate the bioeconomy of enhancement and its effect on how the individuals developed new modes of subjectivation and how they consider their own bodies. We end the article by analysing the transformations of biopower with gene editing and the use of technologies of genetic self-modification by self-experimenters.
\end{abstract}

Keywords: biopower, biopolitics, biocyborg, synthetic biology, human enhancement, gene editing, self-experimentation, biohacking

\section{Introduction}

What does that mean to be normal, ill or enhanced ? There is no sharp distinction between them (Hofmann, 2017). Therapy and enhancement are overlapping concepts, indeed, any successful medical action reflects an enhancement of the condition of the patient even if not all enhancements enhance by being therapeutic (Dekkers and Rikkert, 2007). And there are already socially accepted enhancement practices such as reconstructive surgery which became esthetic surgery, or even vaccination, that can be seen either as prevention medicine or enhancement of the immune system. Therefore, the normal, the pathological and the enhanced have blurred frontier with human enhancement (Hofmann, 2017). In this study, we will consider human enhancement as "any 
kind of genetic, biomedical, or pharmaceutical intervention aimed at improving human dispositions, capacities, or well-being, even if there is not pathology to be treated" (Giubilini et al., 2016). The corresponding technologies have the goal to make a better version of the human body and go beyond the tradition medical enterprise. The aim of human enhancement is not a political and social perfectibility in the sense of the Enlightenment (Le Dévédec, 2014). It is the subject of great debate in different fields and several economic and political strategies since the last 20 years or so (Giubilini et al., 2016; Le Dévédec, 2014; Malet, 2015; Pio-Lopez, 2018; Roco and Bainbridge, 2002). This social phenomenon impacts different domains, from sports (Miah, 2006), the bioeconomy (Lafontaine, 2008) to the military (Malet, 2015), and even found its way in the workplace (Le Dévédec, 2020).

Recently, various scientific and technical advances have emerged. In the context of human enhancement, we think two of them are of particular importance: synthetic biology and gene editing (considered in this study as a sub-field of synthetic biology). Synthetic biology is essentially the application of engineering principles to biology: "Synthetic biology brings together engineering and molecular biology to model, design, and build synthetic gene circuits and other biomolecular components and uses them to rewire and reprogram organisms for a variety of purposes"(May, 2015). This involves building biological organisms from biological components, such as the genetic code, to develop new functions. This technoscience denotes an evolution in the epistemology of biological science. Synthetic biology adopts a constructionist and creationist stances towards biology (Kastenhofer, 2013). The Clustered Regularly Interspaced Short Palindromic Repeats (CRISPR)-Cas9 technology allows gene editing with ease and speed (Shalem et al., 2014). This technology is the result of research in bacteriology and is similar to a genetic scissor allowing the editing by "cut-paste" of the genetic code in a very specific manner, for example by giving the possibility of changing a single nucleotide of the DNA sequence. Gene therapy has been booming since the discovery of CRISPR-Cas9 technology by the Nobel prices Jennifer Doudna, Emmanuelle Charpentier and their team (Doudna and Charpentier, 2014). Before CRISPR, editing the genome was a long, complex and expensive work. The genetic body is now controlled, abolishing the physical frontiers between the flesh and the technology.

We want to contribute to the current debate on the transformations of biopower (Rabinow and Rose, 2006; Rose, 2009). Biopower changed with the molecularization of life and bodies by developing new forms of biopolitics of life, the bioeconomy (that see life as a raw material), biosocialities or biocitizenship (social movements centered on health questions) (Lafontaine, 2008; Plows and Boddington, 2006; Rajan, 2006; Rose, 2009). We analyze how the easy access to new technologies like CRISPR or methods in synthetic biology affected the biopower by empowering the individual that can now change its own genome and how it changes the concept of the race and the role of science. We analyze the activities of a niche group of self genetic experimenters who engineered their genome by means of genetic enhancement tourism or biohacking.

In this study, we advocate that contemporary biotechnological advances of synthetic biology (including gene editing) are transforming the line of forces of biopolitics. After having described the new paradigm of life as engineering, we show using the concept of somatechnology that synthetic biology is transforming the figure of the cyborg towards 
the biocyborg. In second, we first look at the bioeconomy of enhancement and its effect on how the individuals consider their bodies. And we describe the transformations of biopower that synthetic biology offer facilitating the access to technologies of selfmodification of the human genome.

\section{Synthetic biology or biology as technology, and conversely}

Although practitioners and observers define synthetic biology in different ways, the dominant strand and our focus in this article is synthetic biology as the application of the engineering principles to life. Synthetic biology is defined as "the design and construction of new biological parts, devices, and systems", and "the re-design of existing, natural biological systems for useful purposes" (Silver, 2009). The aim is therefore to develop new functions in living organisms. These functions encompass all areas of the bioeconomy, from agriculture to energy and medicine. This (techno)science denotes an evolution in the epistemology of biological science: "Conceptually at least, biology is becoming technology. And physically, technology is becoming biology. The two are starting to close on each other, and indeed as we move deeper into genomics and nanotechnology, more than this, they are starting to intermingle." (Arthur, 2009). The advocates of synthetic biology adopt a position from which they distinguish this field from traditional genetic engineering: "Synthetic biologists position themselves as building an enterprise that will deliver where genetic engineering has failed. This estrangement from established science serves to demarcate synthetic biology and assert its novelty. It also works as a rallying cry and mission statement: synthetic biology will "make biology easier to engineer"' (Schyfter et al., 2013). In this article, we consider new developments in genetic engineering as gene editing with CRISPR as sub-part of synthetic biology understood in a broad sense of engineering life.

Important advances have been made in the last decade in the standardization of biology and the applications. Drew Endy and his colleagues have built a library of what they call biobricks (Smolke, 2009). They are in the public domain so that scientists and students can browse it to see what kinds of innovative biological systems they can create. The biobricks are very present among the materials which push synthetic biology towards engineering, because they offer a standardized system as one can find it in the field of electronics. Advances have also been made in the design of a synthetic cell. Scientists like geneticist Craig Venter used an existing genetic sequence on a computer, synthesized it with a genetic sequencer, and assembled it in the laboratory. Some companies, however, are already turning synthetic biology into cell therapy. As John Collins from MIT explains: "The field is beginning to expand toward engineering therapeutic microbes, living therapeutics." (May, 2015). For example, a microbe could be genetically engineered to detect a particular pathogen and kill it.

The research on the synthetic cell is also targeting the human. One of the most recent large-scale project is the Human Genome Project-write (HGP-write). This scientific project aims to build a synthetic human genome from scratch to better understand the complexity of genetic interaction networks, their functions and mechanisms. This is a typical technoscience effort in order to advance basic science while reducing the costs of large genome synthesis technology. In a nutshell, HGP-write aims to do for DNA 
synthesis what the Human Genome Project (HGP-read) has done for the advancement of sequencing. Recently, experiments have also been conducted on human embryos (Hirakawa et al., 2020) raising several ethical problems on the design of CRISPR babies (Greely, 2019).

It seems that all organisms are now a potential object of engineering. The European Biotechnology Report entitled Making perfect life identified two "megatrends" to describe current research and developments in synthetic biology: biology becoming technology and technology becoming biology (van Est and Stemerding, 2012a).

\begin{abstract}
Biology becoming technology expresses the idea that scientists and engineers increasingly look at living organisms in mechanical terms. It concerns the way in which physical and engineering sciences such as nanotechnology and information technology enable progress in the life sciences. Technology becoming biology is driven by the convergence in the opposite direction, whereby insights into biological and cognitive processes in the life sciences inspire and enable progress within the engineering sciences. Both megatrends point to a future in which the distinction between biology as a science of life and engineering as a science of artefacts will gradually disappear. In other words, both trends evoke a future in which we engage in "making perfect life", with "life" conceived of as a phenomenon that can be controlled and constructed. (van Est and Stemerding, 2012b)
\end{abstract}

Therefore, this evokes an epistemological shift towards an engineering, constructionist or creationist stance in biology (Kastenhofer, 2013; Potthast, 2009). Life can be controlled, optimized and created. This echoes several studies on biopower and biopolitics. Indeed, Nikola Rose founded the concept of "politics of life itself" to describe and understand this transformation of biopower (Rose, 2009). For him, biopolitics is changing towards the control and optimization of life, or in other words to the engineering of life:

It is neither delimited by the poles of illness and death, nor focused on eliminating pathology to protect the destiny of the nation. Rather, it is concerned with our growing capacities to control, manage, engineer, reshape, and modulate the very vital capacities of human beings as living creatures. It is, I suggest, a politics of "life itself". (ibid., p. 7)

Synthetic biology and its tools like CRISPR are in a sense the scientific and technological embodiment of this transformation of biopower. They simplify the manipulation of life for engineering purposes and by an epistemological shift towards engineering, synthetic biology produces inevitably a new truth discourse on life and impacts the ethical debate (Potthast, 2009) and how the individual considers its own body and the potentialities of human enhancement.

\title{
A new anthropological figure: the biocyborg
}

The figure of the cyborg is associated to human enhancement (Clark, 2001). This figure represents the hybridization of man and technology. Historically, the term cyborg is the abbreviation chosen by Clynes and Kline to designate a cybernetic organism. For the two scientists, in order for humans to go into space, their body must be technologically altered and enhanced (Clynes and Kline, 1995). Cybernetics, invented by Norbert Wiener is the science of controlling and regulating systems, be them living or artificial, an the concept of information has a key role in this field. The cyborg is thus a hybrid 
made of flesh and technology. According to Clark, the human would be a "naturalborn cyborg" (Clark, 2001), our brain continuously adapting themselves to the use of external tools becoming internalized prostheses: "We have been designed, by Mother Nature, to exploit deep neural plasticity in order to become one with our best and most reliable tools. Minds like ours were made for mergers. Tools-R-Us, and always have been." (ibid., p.6-7). With this technological anthropology, the discourse of human enhancement finds a legitimisation.

Synthetic biology is developing in all fields of engineering (Andrianantoandro et al., 2006; Purnick and Weiss, 2009) but it is more particularly in the biomedical field that it finds its ramifications with biopower, human enhancement and the figure of the cyborg. This technoscience has applications in the fight against infections, regenerative medicine (Ruder et al., 2011). And it is now possible to inject complex genetic constructs which implements logical programming, by introducing certain molecular compounds into the cell if, and only if, a certain protein is present on the surface of the cell (Macia et al., 2012). It is the biological version of electronic circuits. There is even now a biological implementation of methods from artificial intelligence such as formal neural networks (Nesbeth et al., 2016; Stano et al., 2018).

In the perspective where biology is becoming technology and technology is becoming biology, we think the figure of the cyborg is shifting towards the biocyborg, a complete fusion of man and technology, both sharing the same biological materiality. Dalibert used the concept of somatechnologies to analyse human enhancement technologies: "Somatechnologies are technologies that are acting on and interacting with the body" (Dalibert, 2014). Human enhancement technologies, by acting on human physiology, therefore have to be embodied. But this process is not straighforward:

\footnotetext{
While close to bodies, somatechnologies are not straightforwardly and directly intimate technologies. Rather, they become intimate as they are embodied, embodiment being not only a process but also done by bodies and technologies. For the somatechnology to become transparent, an intensive learning and training process is necessary. One learns to live with somatechnology. This amended embodiment relation - insofar as it is recognised as being done by bodies with technologies and as a (learning) process through which one becomes intimate with somatechnology - does not however exhaust what is at stake with somatechnology. Bodies, their materiality and agency are critical for somatechnologies becoming intimate: they not only influence but also enable it. (ibid., p. 194)
}

In order to become embodied and transparent, the human enhancement technology demands a learning, an interaction with the technology that usually don't share the same materiality, like neural or robotic prosthesis. Synthetic biology solves this problem directly, at least at the materiality level. These technologies are biological matter as the human body, they use genes and their products as a technological process. They are thus directly integrated into the body but can give new functions, like decelerated aging, sharper muscles, an orthogonal immune system, etc. The integration of the technology in the body is straighforward. The prosthetic relationship is pushed to the extreme and seems to fade with this technoscience. With synthetic biology, all prosthetic technoscience could be useless since it would then be possible to regenerate damaged limbs or organs using the dormant regenerative processes of the mammalian organism. In addition, by blurring the lines between the natural and the artificial the technologies of synthetic biology for human enhancement, or bio-somatechnologies may be less a com- 
promise as their integration can be done at the genetic and molecular levels. As Ihde says:

The gradual accumulation of human-technology hybridization, or the cyborg process, often relates to effects of contemporary aging. [...] [C]yborg strategies [which] are often technological attempts to thwart even more severe effects of aging [...] remain trade-offs, compromises. It is better to have a pacemaker than to have life threatening arrhythmia; it is better to be able to walk with either a steel-Teflon implant or a prosthesis than not to walk at all [...] Yet all these trade-off compromises fall far short of the bionic technofantasies so often projected in popular culture. (Ihde, 2008, pp. 38-39)

This primary compromise with synthetic biology of the prosthesis seems to disappear. The cyborg is no longer this man/machine made of flesh and electronic circuits. It is only biological but some of its biochemical processes are artificial and engineered. The technology is now restricted to a more abstract level, the information processing level. In addition, by this share of the same biological materiality, social acceptability could be increased. Indeed, currently, prostheses and artificial limbs are not always fully socially accepted:

Despite their resemblance to the human body, corpses, zombies, and prosthetic hands elicit a negative emotional reaction from those who watch. More concretely, the cosmesis of a prosthetic limb generates a feeling of disappointment. While this allows the body with prosthesis to come across as capable and potentially "fully human", when performance is perceived as mimicry, the body with prosthesis is viewed as deceptive and is "blessed" with insistent, guilty, and even stigmatizing looks. Carried in such a way as to be perceived by oneself and others - that is to say assumed - physically capable of achieving material and visible anonymity, cosmetics, when recognized as a lure, can be extremely damaging and hurtful for the person living with a prosthesis. (Dalibert, 2014, p. 223)

With gene editing and synthetic biology, they can be fully integrated into the body and in fact it could not possible to distinguish with the naked eye an enhanced human from a normal human. The synthetic biology technology and the human shares the same materiality, and potentially the technology is directly embedded and embodied. With the synthetic human or biocyborg, his biology is technology, and his technology is also biology. The prosthetic relationship is somehow abolished as it is no longer possible to clearly distinguish the biological body from the technology. Synthetic biology is blurring the lines between the natural and the artificial.

Bio-somatechnologies of human enhancement raise several ethical questions. One of them is the question of autonomy. Indeed, while it is possible to reject the wearing of glasses and any external prosthesis relatively easily, how to get rid of the addition or deletion of genes? If the body is a technology, this is not without posing a number of political, ethical and body problems. Indeed, is the body a technology ? What does that mean for the individual and society ? The body could be subject for example to improvements cycles as any technology in the industry. Synthetic biology is the bearer of a new vision of living things, and by applying it to the human biology, it also carries a new vision of the human body that we could increase and transform according to our desires (or those belonging to others) by biobricks updates.

By blurring the lines between the artificial and the natural, synthetic biology opens the door to the figure of the biocyborg, that is blurring the lines between the body and technology by pushing back the limits of hybridization. In the next section, we analyze 
how these two tendencies are a perfect fit for the bioeconomy of human enhancement and how they intermingle.

\section{The bioeconomy of human enhancement}

The bioeconomy aims to techno-scientifically exploit the productivity of life and living organisms to answer the contemporary grand challenges such as climate change, food security or health (Bugge et al., 2016). By installing a global economic model, "It is in fact a general development model based on the simple principle that living organisms represent a source of renewable energy from which we can profit economically" (Lafontaine, 2014, p.32). The bioeconomy is inseparable of the transformation of biopower and biopolitics and represents the ultimate phase of global capitalism by monetizing the potential unlimited resources of life (Lafontaine, n.d.). In this perspective, all living things including the human body are perceived as a raw material we can engineer and optimize, which can be improved through technologies:

Initiated with anatomical science, the process of objectifying the body today crystallizes in the transformation of bodily elements into bio-objects while, in the same movement, the body-subject is conceived as a plastic material that can be modified and remodeled to create its identity (Vermeulen et al., 2012). (Lafontaine, n.d.) ${ }^{1}$

In this context, synthetic biology integrates perfectly with the bioeconomy. The body-object has to be modified and more efficient, it is a biocapital the individual have to invest in. The individuals are indeed an important actor in the bioeconomy, that aims to make them responsible towards their biological heritage. Identitites are more than ever biological (Lafontaine, 2014), which leads to the development of new forms of citizenchip (or sociality):

The notion of biocitizenship refers to all social movements focused on health issues, in a very broad sense. This includes issues relating to reproduction, aging, death as well as those relating to the improvement of the human body. In this sense, the bioeconomy is inseparable from biocitizenship, that is, a new form of citizenship centered on the optimization of the biological and bodily potentials of individuals. (Lafontaine, 2017) ${ }^{2}$

New forms of biocitizenship includes for example the movement for the right to experimentation, medical tourism or biobanks (ibid.). With the blurring lines between therapy and enhancement (Hofmann, 2017), and the controlling/engineering paradigm on life, a bioeconomy of enhancement emerged. One of the most emblematic field is probably the anti-aging industry. The dream of pushing back lifespan is as old as human civilization. Various genetic, dietary and pharmacological interventions have been

\footnotetext{
1“Amorcé avec la science anatomique, le processus d'objectivation du corps se cristallise de nos jours dans la transformation d'éléments corporels en bio-objets tandis que, dans un même mouvement, le corpssujet est conçu comme une matière plastique pouvant être modifiée et refaçonnée afin de créer son identité (Vermeulen et al., 2012)". (Lafontaine, n.d.)

2"La notion de biocitoyenneté réfère à l'ensemble des mouvements sociaux centrés sur des questions de santé, dans un sens très large. Cela inclut les questions relatives à la reproduction, au vieillissement, à la mort ainsi que celles qui touchent à l'amélioration du corps humain. En ce sens, la bioéconomie est indissociable de la biocitoyenneté, c'est-à-dire d'une nouvelle forme de citoyenneté centrée sur l'optimisation des potentialités biologiques et corporelles des individus." (Lafontaine, 2017)
} 
shown to increase lifespan, sometimes dramatically (doubling is possible), in short-lived model organisms such as yeast, worms, flies, mices or rats (Kenyon, 2010; Tacutu et al., 2012). The human is now the new target. The potential benefits of this market are enormous. However, the anti-aging industry can not be reduced only to the pursuit of financial benefit:

\begin{abstract}
In the case of biomedical technologies, it is clear that the hope of curing still incurable diseases, of preventing cancer and of delaying the harmful effects of aging comes from a system of values that goes far beyond simple financial matters. The diversion of the promises of science in favor of biocapital appears in this all the more significant because it is based on deep anthropological springs. When we mobilize the fear of death and the quest for eternal youth, it is in fact the value of life itself that is brought into play; not only in its material reality (zoe) but in its existential dimension (bios). (Lafontaine, 2014, pp. $45-46)^{3}$
\end{abstract}

The bioeconomy carries a new vision of life that fits perfectly with the synthetic biology paradigm of life as engineering. This bioeconomy of enhancement is not restricted to anti-aging and spreads in cognitive (Bostrom and Sandberg, 2009), military (Malet, 2015; Pio-Lopez, 2018), or physical enhancement (Cakic, 2009). In the next section, we analyze the new biosocialities centered on genetic enhancement and selfexperimentation that are emerging.

\title{
Gene editing: power of technology and technology of power
}

In the context of the bioeconomy of enhancement, a new form of biosociality emerged centered on genetic enhancement and self-experimentation by means of genetic enhancement tourism and biohacking. This niche group of self-experimenters wants to enhance their bodies at the genetic level raising questions on the role of science or the ethics of self-experimentation. By pushing their bodies on the frontline and by transforming it at the genetic level outside any medical mediation, they are also moving the lines of forces of biopolitics.

Elizabeth Parrish claimed two gene therapies in Colombia in order to increase the size of her telomeres, fragments of DNA at the end of chromosomes that become shorter with age, and to block the effects of myostatin which causes muscle wasting during aging (Hamzelou, 2017). She is the CEO of Bioviva, an anti-aging company and she describes herself as "patient zero" (Regalado, 2015) and represents perfectly the postmortal society (Lafontaine, 2008) when she says "I have aging as a disease" (Regalado, 2015). Her vision of the future of health is the following:

Those humans alive 200 years from now will have exquisite control over their health and wellbeing through advanced cell technologies that can only be imagined by people living today. The risk takers - those who can already envision surpassing the limits of their bodies

\footnotetext{
3"'Dans le cas des technologies biomédicales, il est clair que l'espoir de guérir des maladies encore incurables, de prévenir le cancer et de retarder les effets néfastes du vieillissement procède d'un système de valeurs qui dépasse largement les simples questions financières. Le détournement des promesses de la science au profit du biocapital apparaît en cela d'autant plus prégnant qu'il s'appuie sur des ressorts anthropologiques profonds. Lorsqu'on mobilise la peur de la mort et la quête d'une jeunesse éternelle, c'est en fait la valeur de la 'vie en elle-même' qu'on met en jeu; non pas uniquement dans sa réalité matérielle (zoe) mais dans sa dimension existentielle (bios)”. (Lafontaine, 2014, pp. 45-46)
} 
and those who are unwilling to accept the disability of old age without a fight - will be the ones pioneering a bold future and reinventing our concept of health. (Parrish, 2017)

She is one of the risk takers she describes. Indeed, she pushed her own body in the front line by receiving a highly experimental gene therapy procedure to fight aging. The result of her gene editing have been partially verified by the scientific community. The MIT Technology Review spoke with the director Matthew Andrews who accompanied Parrish during the medical procedure and who confirmed that it had indeed been carried out (Regalado, 2015). In September 2015, before her gene therapy, she sent her white blood cells for analysis to the SpectraCell laboratory and in March 2016, in post-therapy, she had them analyzed by this same laboratory. Analyses show that her telomeres are indeed longer and have gone from $6.71 \mathrm{~kb}$ (kilobases) to $7.33 \mathrm{~kb}$ (Garcia, 2016). According to Parrish, from a biological point of view, this would be equivalent to an addition of twenty years of life more or less.

Her case highlights a new aspect of medical tourism after reproductive tourism and last chance tourism for terminally ill patients. Individuals can now practice a new form of medical tourism by buying an enhancement in a foreign country. Even if it has not been clinically tested. It is to our knowledge an isolated case of enhancement tourism, nevertheless, it raises several questions on contemporary biopolitics. Indeed, Parrish decided to apply a highly experimental genetic engineering operation in a foreign country because her own does not allow such an intervention. She claims about how to develop new gene therapies:

"I would have to go raise almost a billion dollars. It would take about 15 years of testing. And when I'm looking out there, I'm seeing people who don't want to wait 15 years." The crowd began clapping, and Parrish fed off it. "How do we actually change this paradigm? Well, what we do is we burn and raze everything to the ground. And we start over." (Funk, 2018)

Parrish does not want to follow the terms of the bioethics of biomedical research. "Here, the research process is individuated, collapsing the researchers-subject relationship. If we view the person as single, bounded and continuous, then when the practitioner and subject are the same person, their duty of care is arguably void." (Addison, 2020). This kind of self-experimentation is not an isolated case, a new social phenomenon appeared with the decreasing cost of the synthetic biology technologies: enhancement via biohacking.

Biohacking can be defined as follows: "Although there is no consensus on the precise definition of 'biohacking', the term generally describes biological investigations and interventions that are conducted outside of typical scientific settings by individuals who may not have traditional scientific training" (Zettler et al., 2019a). This activity has developed in parallel with research in synthetic biology and in the development of fablabs, these manufacturing workshops, open and civilian research laboratories. Born in the late 2000s, this practice has since spread around the world. With the miniaturization and decreasing costs of molecular biology and genetics technologies, it is possible at low cost to have a small laboratory in your garage (Gaspar et al., 2019). The movement wants to reclaim biology, "if personal computing exists, why not biotechnology?" (Jorgensen, 2016). In this context, two biohackers hit the headlines by practicing visual enhancement by injecting a chlorine molecule into the eye, making the retinal cells very 
photosensitive, thus allowing the patient to see at night. It is a compound that is found in particular in fish living in deep waters. The results were published as a scientific article (Licina and Tibbetts, 2015).

The trend concerns also genetic enhancement. The former NASA biochemist Josiah Zayner injected himself a CRISPR solution the october 4, 2017 on live streaming. He is the CEO (like Parrish) of The Odin which sold CRIPSR-Cas9 kits for 1700 dollars. The goal of his procedure was to inactivate the gene responsible for myostatin production to see if it will allow him to build more muscle. This project aimed to establish the proof of concept that it is possible to practice gene therapy at home, with a minimum of material and cost (Ignasse, 2017). As Zayner himself claimed it, "I want to help humans genetically modify themselves" (Ireland, 2017) and it just seems easier: "People don't know that generally the same resources that are available to scientists are available to non-scientists. I can just order DNA online and they ship it to my house. If I want to get some sequencing done I send it off to a company and they'll do it for me. It's really inexpensive - we're talking 6 dollars to get a sample sequenced, or 10 dollars to get a piece of DNA"(ibid.). As Parrish, Zayner envisions a bright future where genetic enhancement is a common practice:

To me it's like Bladerunner, where he goes into that backalley science lab and there's the guy making eyes. I imagine people going to some place like a tattoo parlour, and instead of getting a tattoo they pick out some DNA that makes them muscly, or changes the colour of their hair or eyes. DNA defines what a species is, and I imagine it wouldn't be too long into the future when the human species almost becomes a new species because of these modifications. (ibid.)

The result of his genetic editing does not appear to have been scientifically and medically verified, it was nonetheless emulated. On February 4, 2018, it was the turn of Aaron Traywick, CEO of the biotechnology company Ascendance Biomedical to practice genetic biohacking by injecting an experimental treatment against herpes in front of the cameras at the Body Hacking conference in Austin (Mullin, 2018). His company had already been involved in this kind of experiment in October 2017 with the injection of an experimental gene therapy against the HIV virus (Lussenhop, 2017).

Until now, these activities of gene enhancement can be reported as self-experimentation. However, when this self-experimentation is undertaken by groups coordinating their efforts, these activities may look like "decentralized clinical trials" (Zettler et al., 2019b). In addition, biohackers are approached by indviduals asking for help to treat their own diseases or those of related and a possible case is that biohackers could try to experiment on others (ibid.).

These cases of self-experimentation show how individuality and body identity are changing in our societies and how they are used by the bioeconomy of enhancement. With post-genomics and predictive medicine, the goal was to maximize its biological potential with the existing body:

For example, the entire predictive medicine and personalized medicine project is based on the idea that each individual should know their genetic profile in order to prevent certain physical failures or, more positively, to maximize their biological potential. In fact, identity in the post-genomic era is more biological than ever, as the life sciences have completely changed the way human life is conceived. (Lafontaine, 2014, pp. 55-56) ${ }^{4}$

\footnotetext{
${ }^{4} \mathrm{~A}$ titre d'exemple, tout le projet de la médecine prédictive et de la médecine personnalisée repose sur
} 
In the case of Parris, Zayner or Traywick, it is not only a question of knowing her genetic profile in order to anticipate the onset of diseases linked to aging but to transform their own bodies, to change the hardware in a sense, to alter their genetic profile. Previously, the biocapital of one individual was fixed and the goal was to maximize it. With the new technologies of the synthetic biology, by using a financial metaphor, their goal is to diversify their biocapital. A new form of biocapital risk in a sense, by paying for highly experimental therapies and assuming the associated risks. It is a new form "clinical labour" (Cooper and Waldby, 2014).

Authorities are therefore concerned by these biotechnologies of enhancements and their use. Synthetic biology and CRISPR kit have been recently the subject of a new biopolitics centered on security and regulation (Kelle, 2009). But the particular case of self genetic enhancement has been investigated only recently by the law. In 2019, California enacted the first CRISPR law that prevents companies from selling CRISPR kits designed to modify human DNA and the same year California's Department of Consumer Affairs investigated Josiah Zayner for the unlicensed practice of medicine (Zettler et al., 2019a).

The risks at stake not only concern the individual with all the potential side-effects of gene therapy, they also concern the human species and reproduction. Indeed, gene editing has also been applied recently to embryos: gene-edited twin girls are reportedly born, and a second pregnancy with a third gene-edited embryo has been established (Cyranoski, 2019). It is therefore possible to apply CRISPR on germline cells. This raises several ethical and biopolitical problems concerning the race and reproduction, two main themes of biopolitics (Rabinow and Rose, 2006). The International Summit on Human Gene Editing summarized the different risks associated to gene editing :

(i) the risks of inaccurate editing (such as off-target mutations) and incomplete editing of the cells of early-stage embryos (mosaicism); (ii) the difficulty of predicting harmful effects that genetic changes may have under the wide range of circumstances experienced by the human population, including interactions with other genetic variants and with the environment; (iii) the obligation to consider implications for both the individual and the future generations who will carry the genetic alterations; (iv) the fact that, once introduced into the human population, genetic alterations would be difficult to remove and would not remain within any single community or country; (v) the possibility that permanent genetic "enhancements" to sub-sets of the population could exacerbate social inequities or be used coercively; and (vi) the moral and ethical considerations in purposefully altering human evolution using this technology. (Olson et al., 2016)

The main concern is probably relative to the human race and evolution. If gene editing can be transmitted to the next generation, what does that mean for the race ? Indeed, a new evolution could appear, controlled by the individual in the case of biohacking with self-genetic enhancement or controlled by rogue scientists in the case of CRISPR babies (Greely, 2019). The risk is real, indeed, according to researchers in astrophysics, the minimum viable population to start a new colony (or human species) on another planet is only 98 (Marin and Beluffi, 2018). The number seems very low to start a new species.

l'idée que chaque individu devrait connaître son profil génétique afin de prévenir certaines défaillances physiques ou, plus positivement, maximiser son potentiel biologique. En fait l'identité à l'ère postgénomique est plus biologique que jamais, dans la mesure où les sciences du vivant ont complètement modifié la conception de la vie humaine. (Lafontaine, 2014, pp. 55-56) 
The power of CRISPR technology is very important, it empowers the individual, gives him a direct control on his genome and as a consequence it has the potential to change the human race. Foucault defines biopower as:

[...] a physics of power, or a power thought of as physical action in the element of nature, and a power thought of as regulation that can only be carried out through and by reliance on the freedom of each, is, I think, something absolutely fundamental. It is not an ideology; it is not exactly, fundamentally, or primarily an ideology. First of all and above all it is a technology of power. (Foucault, 2007, p. 49)

But in this sense, associated to the discourse of truth of synthetic biology and genetic biohacking, it becomes a technology of power. Gene editing adds a layer of control to the power over life but this level is also the biological basis of our definition of the race and it is no longer fixed. With CRISPR, it is now possible to act on it according to our desires and practice a non-darwinian evolution. The body is in a sense, using a Foucaldian term, genetically disciplined.

\section{Conclusion}

The advances of synthetic biology and the easy and low-cost access to biotechnologies of enhancement and gene editing are transforming the biopower. From genome description and anticipated medical action, the tendency has shifted to a profound reprogramming of the body and genome. The spread of human enhancement in a selfexperimentation context is emerging that needs further investigation in the social and political science. The aim of this article was to show the interplay between the bioeconomy, the new paradigm of synthetic biology, and how it gives raise to the figure of the biocyborg and new social phenomena centered on self-experimentation and genetic enhancement. By opening up the possibility to change our own genome without any medical mediation, genetic enhancement can significantly transform the biopower, bodies, race and reproduction. Indeed, if any individual with minimal training can change their genes, the individual pave the way towards a new human race. More speculatively, with CRISPR, a human could even be its own race. With the self-experimenters, we observe new modes of subjectivation where the individual don't hesitate to put his body in the frontline for genetic self-experimentation and enhancement. This new "enhancement labour" should be studied more extensively, particularly given the transformations of biopower it implies and how it impacts the role of science and medicine. The capitalist logic turned life as a raw material with the bioeconomy, this logic is now strenghtened with the advances of synthetic biology and gene editing and in the current state it opens the door to a complete liberal eugenics.

\section{Acknowledgements}

I thank Damien Depannemaecker for comments that greatly improved the manuscript. 


\section{References}

Addison, C. (2020). Crispr cowboys? genetic self-experimentation and the limits of the person. Personhood in the age of biolegality (pp. 149-166). Springer.

Andrianantoandro, E., Basu, S., Karig, D. K., \& Weiss, R. (2006). Synthetic biology: New engineering rules for an emerging discipline. Molecular systems biology, 2(1).

Arthur, W. B. (2009). The nature of technology: What it is and how it evolves. Simon; Schuster.

Bostrom, N., \& Sandberg, A. (2009). Cognitive enhancement: Methods, ethics, regulatory challenges. Science and engineering ethics, 15(3), 311-341.

Bugge, M. M., Hansen, T., \& Klitkou, A. (2016). What is the bioeconomy? a review of the literature. Sustainability, 8(7), 691.

Cakic, V. (2009). Smart drugs for cognitive enhancement: Ethical and pragmatic considerations in the era of cosmetic neurology. Journal of medical ethics, 35(10), 611-615.

Clark, A. (2001). Natural-born cyborgs? Cognitive technology: Instruments of mind (pp. 17-24). Springer.

Clynes, M. E., \& Kline, N. S. (1995). Cyborgs and space. The cyborg handbook, 29-34.

Cooper, M., \& Waldby, C. (2014). Clinical labor: Tissue donors and research subjects in the global bioeconomy. Duke University Press.

Cyranoski, D. (2019). The crispr-baby scandal: What's next for human gene-editing.

Dalibert, L. (2014). Posthumanism and somatechnologies: Exploring the intimate relations between humans and technologies.

Dekkers, W., \& Rikkert, M. O. (2007). Memory enhancing drugs and alzheimer's disease: Enhancing the self or preventing the loss of it? Medicine, Health Care and Philosophy, 10(2), 141.

Doudna, J. A., \& Charpentier, E. (2014). The new frontier of genome engineering with crispr-cas9. Science, 346(6213).

Foucault, M. (2007). Security, territory, population: Lectures at the collège de france, 1977-78. Springer.

Funk, M. (2018). Liz parrish wants to live forever. Retrieved April 23, 2020, from https: //www.outsideonline.com/2325556/liz-parrish-live-forever

Garcia, V. (2016). Une scientifique assure avoir "rajeuni" de 20 ans grâce à une thérapie génique. Retrieved April 23, 2018, from https ://www. lexpress.fr/actualite/ sciences / une - scientifique - assure - avoir - rajeuni - de - 20 - ans - grace - a - une therapie-genique_1786793.html

Gaspar, R., Rohde, P., \& Giger, J.-C. (2019). Unconventional settings and uses of human enhancement technologies: A non-systematic review of public and experts' views on self-enhancement and diy biology/biohacking risks. Human Behavior and Emerging Technologies, 1(4), 295-305.

Giubilini, A., Sanyal, S., Clarke, S., Savulescu, J., \& Coady, C. (2016). The ethics of human enhancement: Understanding the debate.

Greely, H. T. (2019). Crispr'd babies: Human germline genome editing in the 'he jiankui affair'. Journal of Law and the Biosciences, 6(1), 111-183.

Hamzelou, J. (2017). Time to stop getting old. 
Hirakawa, M. P., Krishnakumar, R., Timlin, J. A., Carney, J. P., \& Butler, K. S. (2020). Gene editing and crispr in the clinic: Current and future perspectives. Bioscience Reports, 40(4).

Hofmann, B. (2017). Limits to human enhancement: Nature, disease, therapy or betterment? BMC medical ethics, 18(1), 1-11.

Ignasse, J. (2017). Un biohacker tente de devenir un surhomme en modifiant son adn. Retrieved April 23, 2018, from https ://www. sciencesetavenir.fr/sante/ un biohacker-ancien-de-la-nasa-tente-de-devenir-un-surhomme-en-modifiantson-adn_118663

Ihde, D. (2008). Ironic technics. Automatic Press/VIP.

Ireland, T. (2017).

i want to help humans genetically modify themselves'. Retrieved April 23, 2018, from https://www.theguardian.com/science/2017/dec/24/josiah-zayner-diygene-editing-therapy-crispr-interview

Jorgensen, E. (2016). Biohacking, you can do it too. Retrieved April 23, 2018, from https://www.ted.com/talks/ellen_jorgensen_biohacking_you_can_do_it_too? language $=\mathrm{fr}$

Kastenhofer, K. (2013). Synthetic biology as understanding, control, construction, and creation? techno-epistemic and socio-political implications of different stances in talking and doing technoscience. Futures, 48, 13-22.

Kelle, A. (2009). Ensuring the security of synthetic biology-towards a 5 p governance strategy. Systems and synthetic biology, 3(1-4), 85.

Kenyon, C. J. (2010). The genetics of ageing. Nature, 464(7288), 504.

Lafontaine, C. (n.d.). Mon corps, mon capital. la bioéconomie et les nouvelles frontières du corps humain. Etica \& Politica/Ethics \& Politics.

Lafontaine, C. (2008). La société post-mortelle. Paris, Seuil (deutsch: Die postmortale Gesellschaft, VS Verlag, 2010).

Lafontaine, C. (2014). Le corps-marché. la marchandisation de la vie humaine à l'ère de la bioéconomie: La marchandisation de la vie humaine à l'ère de la bioéconomie. Le Seuil.

Lafontaine, C. (2017). La biocitoyenneté à l'ère du néolibéralisme. Relations, (792), 23-26.

Le Dévédec, N. (2014). La société de l'amélioration: Le renversement de la perfectibilité humaine, de l'humanisme des lumières à l'humain augmenté.

Le Dévédec, N. (2020). The biopolitical embodiment of work in the era of human enhancement. Body \& Society, 26(1), 55-81.

Licina, G., \& Tibbetts, J. (2015). A review on night enhancement eyedrops using chlorin e6. Science for the mass.

Lussenhop, J. (2017). Why i injected myself with an untested gene therapy. Retrieved April 23, 2018, from http://www.bbc.com/news/world-us-canada-41990981

Macia, J., Posas, F., \& Sole, R. V. (2012). Distributed computation: The new wave of synthetic biology devices. Trends in biotechnology, 30(6), 342-349.

Malet, D. (2015). Captain america in international relations: The biotech revolution in military affairs. Defence Studies, 15(4), 320-340. 
Marin, F., \& Beluffi, C. (2018). Computing the minimal crew for a multi-generational space travel towards proxima centauri b. arXiv preprint arXiv:1806.03856.

May, M. (2015). Synthetic biology's clinical applications. Retrieved April 23, 2018, from http ://www. sciencemag . org / features / 2015/09/synthetic - biology - s clinical-applications

Miah, A. (2006). Rethinking enhancement in sport. Annals of the New York Academy of Sciences, 1093(1), 301-320.

Mullin, E. (2018). 2017 was the year of gene-therapy breakthroughs. Retrieved April 23, 2018, from https://www.technologyreview.com/s/609643/2017-was-theyear-of-gene-therapy-breakthroughs/

Nesbeth, D. N., Zaikin, A., Saka, Y., Romano, M. C., Giuraniuc, C. V., Kanakov, O., \& Laptyeva, T. (2016). Synthetic biology routes to bio-artificial intelligence. Essays in biochemistry, 60(4), 381-391.

Olson, S., on Science, C., National Academies of Sciences, E., Medicine et al. (2016). International summit on human gene editing: A global discussion. International summit on human gene editing: A global discussion. National Academies Press (US).

Parrish, E. (2017). One year anniversary of bioviva's gene therapy against human aging. https://bioviva-science.com/blog/2017/3/2/one-year-anniversary-of-biovivasgene-therapy-against-hu-man-aging

Pio-Lopez, L. (2018). Biopolitique et transhumanisme: Approches politique, sociale et stratégique (Master's thesis). Université Jean-Moulin Lyon 3.

Plows, A., \& Boddington, P. (2006). Troubles with biocitizenship? Genomics, Society and Policy, 2(3), 115.

Potthast, T. (2009). Paradigm shifts versus fashion shifts? systems and synthetic biology as new epistemic entities in understanding and making'life'. EMBO reports, 10(S1), S42-S45.

Purnick, P. E., \& Weiss, R. (2009). The second wave of synthetic biology: From modules to systems. Nature reviews Molecular cell biology, 10(6), 410.

Rabinow, P., \& Rose, N. (2006). Biopower today. BioSocieties, 1(2), 195-217.

Rajan, K. S. (2006). Biocapital: The constitution of postgenomic life. Duke University Press.

Regalado, A. (2015). A tale of do-it-yourself gene therapy. Retrieved April 23, 2018, from https://www.technologyreview.com/s/542371/a-tale-of-do-it-yourselfgene-therapy/

Roco, M. C., \& Bainbridge, W. S. (2002). Converging technologies for improving human performance: Integrating from the nanoscale. Journal of nanoparticle research, 4(4), 281-295.

Rose, N. (2009). The politics of life itself: Biomedicine, power, and subjectivity in the twenty-first century. Princeton University Press.

Ruder, W. C., Lu, T., \& Collins, J. J. (2011). Synthetic biology moving into the clinic. Science, 333(6047), 1248-1252.

Schyfter, P., Frow, E., \& Calvert, J. (2013). Guest editorial: Synthetic biology: Making biology into an engineering discipline. 
Shalem, O., Sanjana, N. E., Hartenian, E., Shi, X., Scott, D. A., Mikkelsen, T. S., Heckl, D., Ebert, B. L., Root, D. E., Doench, J. G. et al. (2014). Genome-scale crisprcas9 knockout screening in human cells. Science, 343(6166), 84-87.

Silver, P. A. (2009). Making biology easier to engineer. Biosocieties, 4(2-3), 283-289.

Smolke, C. D. (2009). Building outside of the box: Igem and the biobricks foundation. Nature biotechnology, 27(12), 1099-1102.

Stano, P., Kuruma, Y., \& Damiano, L. (2018). Synthetic biology and (embodied) artificial intelligence: Opportunities and challenges. Adaptive Behavior, 26(1), 4144.

Tacutu, R., Craig, T., Budovsky, A., Wuttke, D., Lehmann, G., Taranukha, D., Costa, J., Fraifeld, V. E., \& De Magalhães, J. P. (2012). Human ageing genomic resources: Integrated databases and tools for the biology and genetics of ageing. Nucleic acids research, 41(D1), D1027-D1033.

van Est, R., \& Stemerding, D. (2012a). Making perfect life: European governance challenges in 21st century bio-engineering-final report. European Parliament, STOA.

van Est, R., \& Stemerding, D. (2012b). Making perfect life: European governance challenges in 21st century bio-engineering-study summary.

Vermeulen, N., Tamminen, S., \& Webster, A. (2012). Bio-objects: Life in the 21st century. Ashgate Publishing, Ltd.

Zettler, P. J., Guerrini, C. J., \& Sherkow, J. S. (2019a). Finding a regulatory balance for genetic biohacking. Consuming Genetic Technologies: Ethical and Legal Considerations, Cambridge Univ. Press, Forthcoming.

Zettler, P. J., Guerrini, C. J., \& Sherkow, J. S. (2019b). Regulating genetic biohacking. Science, 365(6448), 34-36. 